\title{
A Diagnosis and Some Remedies for Spanish Criminal Justice Policy
}

\author{
José Luis Díez-Ripollés
}

\begin{abstract}
The study starts by describing some social facts and political factors which can explain the unstable and unsatisfactory criminal justice policy that Spain is currently suffering from. The paper then unveils and questions some misconceptions frequently used to justify ill-founded criminal justice policy decisions. The study next focuses on highlighting the analytical framework which could rebuild the ideological and pragmatic consistency of Spanish criminal policy. The second half of the paper is devoted to a thorough reflection on a couple of legal and organisational reforms which cannot be postponed: the reform of the sanctions system, and the modernisation of the criminal justice administration.
\end{abstract}

\section{Introduction}

Criminal policy has been at the centre of intense debates in Spanish society for over the last two decades. This has led to an important number of political initiatives aimed at renewing the criminal justice system.

It was only quite recently that the old criminal code of 1848 , reformed so many times, was replaced by a new criminal code in 1995. Never before in the past, despite its ongoing deficiencies, had the criminal justice administration been subject to a modernisation process such as that of the last decade. Moreover, Spain's penitentiary system, having been well regulated since the return to democracy, mostly operates out of newly built facilities, thus making it one of the best equipped in Europe.

However, all these efforts have not managed to dispel a generalised sensation of dissatisfaction with the outcomes achieved, which have resulted in very different proposals as to which is the road to follow. In the political field this has led to hectic and rash legislative activity, which has already produced approximately thirty reforms to the criminal code in 15 years, not including the numerous legal and organisational changes in every sector involved with the criminal justice system.

The following reflections intend to draw attention to a set of social and political factors that may account for the current situation, in order to then debate which should be the path to be followed by a consistent criminal policy, something which is currently lacking. Finally, some of the most urgent pending tasks shall be pointed out.

\footnotetext{
* Dr José Luis Díez-Ripollés, Professor of Criminal Law and Head od the Andalusian Interuniversity Institute of Criminology, University of Málaga (Spain)
} 


\section{Some social facts}

It can be reasonably asserted that Spain enjoys a low crime rate, in fact, one of the lowest in Western Europe, a region which moreover occupies one of the best positions globally speaking.

Before Spain's police crime statistics regrettably became a useless instrument ${ }^{1}$, the country had one of the lowest rates in Western Europe ${ }^{2}$. As for their evolution in the past decade, a moderate, increasing tendency was registered, which has apparently eased in these past years ${ }^{3}$.

A similar picture is obtained from victimisation surveys, with Spain occupying the last place in terms of prevalence or victimisation rates among the 18 countries of the European Union on which this rate was measured in $2004^{4}$. With regards to its evolution, it can be noticed that the aforementioned rate, in relation to the personal experience of the past five years, shows a significant drop from 1989 to 2008, whereas if personal experiences in the last year are examined, both the prevalence and incidence or frequency rates drop noticeably from 1989 to 2005, rising slightly towards $2008^{5}$.

At the same time, from the mid-90s onwards, our criminal justice system is based on an excessive use of the prison penalty, a factor that has become even more pronounced in recent years. The problem is not that many people are sentenced to prison, something which would be inconsistent with our low crime rates, but that inmates spend a lot of time deprived of their liberty due to the excessive prison sentences imposed on them ${ }^{6}$, and to the limited use of anticipated prison release ${ }^{7}$. This factor has enabled Spain to recently achieve a level of punitive excellence in Western Europe: Spain's imprisonment rate, 163 inmates every 100,000 inhabitants,

\footnotetext{
${ }^{1}$ Around 2007. See Aebi/Linde, El misterioso caso de la desaparición de las estadísticas policiales españolas, Revista electrónica de Ciencia penal y criminología, 2010, passim, and the article signed by directors of different academic and research institutions on Criminology, Díez Ripollés/A. Giménez-Salinas, La opacidad de las cifras del crimen, Público (newspaper), March 19 $19^{\text {th }}, 2010$.

${ }^{2}$ In 2006, only Portugal and Italy were below Spain. See European Sourcebook of Crime and Criminal Justice Statistics. $4^{\text {th }}$ edition. 2010. WODC. P. 37.

${ }^{3}$ Although the data from 2007 onwards must be taken very cautiously for the aforementioned reasons. See the information gathered in García España/Díez Ripollés/Pérez Jiménez/Benitez Jiménez/Cerezo Domínguez, Evolución de la delincuencia en España: Análisis longitudinal con encuestas de victimización, Revista española de investigación criminológica (REIC), No 8. 2010, www.criminologia.net p. 3.

${ }^{4}$ See v.Dyk/Manchin/v. Kesteren/Nevala/Hideg, The Burden of Crime in the EU. A Comparative Analysis of the European Survey of Crime and Safety (EU ICS), 2005, pp. 19-20.

${ }^{5}$ See Díez Ripollés/García España drs., Encuesta a víctimas en España, Instituto andaluz interuniversitario de Criminología/Fundación Cajasol, 2009, pp. 39, 41.

${ }^{6}$ The duration of the average stay in prison has increased from 9.7 months in 1996 to 18 months in 2007. During this year, the average stay in prison at least doubled the figures for England and Wales, Germany and France, and tripled those of Italy; only Rumania and Portugal within the European Union had longer average stays. See Aebi/ Delgrande, Annual Penal Statistics, Space I, Survey 2008”, Council of Europe, 2010, pp. 87-89; Cid Larrauri, Bericht Spanien", in Dünkel/Lappi-Seppäla/Morgenstern/v. Zyl Smit (eds.), Kriminalität, Kriminalpolitik, strafrechtliche Sanktionspraxis und Gefangenenraten in europäischen Vergleich, Band 2, Forum Verlag Godesberg, 2010, p. 784.

${ }^{7}$ It is estimated that in 2006 only $29 \%$ of those sentenced to prison in Spain -in Catalonia the percentage is even reduced to 22\%- ended their sentence with parole. See Cid Moliné, El incremento de la población reclusa en España entre 1996-2006: Diagnóstico y remedios, Revista española de investigación criminológica (REIC), http://www. criminologia.net, 2008, n. 2, pp. 17-20. For comparative data in Europe, see Tébar Vilches, El modelo de libertad condicional en España, Aranzadi 2006, pp. 216-217.
} 
is the highest of all the countries in the region, and among the most populated of these countries, it only holds a slight resemblance to England and Wales -150/ $100,000-$, as opposed to Italy $-113 / 100,000-$, France $-96 / 100,000$ - or Germany $-88 / 100,000-{ }^{8}$.

The social agents in charge of operating the criminal justice system have very different levels of social credibility: as opposed to what occurred during the last years of the dictatorship and the first years of the transition to democracy, the different police bodies now enjoy significant credibility, placing them among the most positively valued institutions in the country. In contrast, the judiciary and the penitentiary administration suffer a very low level of trust, placing them among the worst valued institutions of our political system. In a recent survey on the level of trust that citizens place on the aforementioned institutions, $80 \%$ declared they trusted the police a lot or quite a lot, less than $40 \%$ held the same opinion with regards to the judiciary, whilst the penitentiary administration barely reached $34 \%{ }^{9}$.

Crime is a subject of continuous and prominent attention in the media. Crime and accident reports frequently occupy the front pages and headlines of all mass media ${ }^{10}$. Although, fortunately, we are not experiencing an increase in tabloid press as in other neighbouring countries, the serious press is highly contaminated by the tendency to give priority to this type of information. The effects of this transformation on informative priorities are socially ambivalent: on the one hand, they have a considerable normative-compliance role, since they promote the internalisation of criminal prohibitions among the population. On the other hand, however, they produce noticeable cognitive distortions, both in terms of the real nature and frequency of crime ${ }^{11}$, as well as the way the institutions in charge of the criminal justice system actually operate, thus having direct repercussions on the subsequent adoption of criminal policy decisions. On some occasions, severe scrutiny of the performance of these institutions leads to strongly biased attitudes that discredit the way these operate ${ }^{12}$.

New victim pressure groups have emerged that have a real and defining influence on the legislative decision-making process and, more diffused but with similar effects, on the sentencing and correctional levels ${ }^{13}$. These groups can respond to very different interests, but those which currently stand out belong to feminist groups,

\footnotetext{
${ }^{8}$ The figures correspond to 2010 -except for France, which date from 2008- from the International Centre for Prison Studies, King's College London, http://www.kcl.ac.uk/schools/law/research/icps.

${ }^{9}$ See Díez Ripollés/García España drs., Encuesta a víctimas en España, op. cit. pp. 152-155. For other results that run along a similar line, see Díez Ripollés, El nuevo modelo penal de la seguridad ciudadana, Revista electrónica de ciencia penal y criminología (RECPC), http://criminet.ugr.es/recpc, p. 11.

${ }^{10}$ This is a well-known fact. See some illustrative analyses in Soto Navarro, La delincuencia en la agenda mediática, Revista española de investigaciones sociológicas (REIS), 2005, nº 112, pp. 75-130; García Arán/Botella Corral drs., Malas noticias. Medios de comunicación, política criminal y garantías penales en España, Tirant 2008, passim; Landrove Díaz, El nuevo derecho penal, Tirant 2009, pp. 63-67.

${ }^{11}$ See above.

${ }^{12}$ Reports on court activities by journalists of the newspaper El País, such as Yoldi or Martínez Lázaro, are sometimes a good example from one of the most influential media.

${ }^{13}$ See a specific analysis of this phenomenon in Cerezo Domínguez, El protagonismo de las víctimas en la elaboración de las leyes penales, Tirant 2010, passim; also, among others, Landrove Díaz, op. cit. pp. 60-62, 147-148.
} 
victims of terrorism or those related to juvenile delinquency. Their influence has been clearly felt in the repeated expansion of criminal reactions against domestic or partner violence, recently renamed gender violence, in the more comprehensive provisions regarding terrorism and the simultaneous harshening of the penitentiary regime applicable to those condemned for these crimes, and in the successive reforms of juvenile criminal law that have practicably de-naturalised it. All this has given rise to a noticeable loss of balance among the pressure groups that are usually influential in the design and implementation of criminal policy: not only have the social movements that used to counterweight the interests of the victims disappeared, such as the organisations for prisoners' rights, but the expert pressure groups, with the exception of the police, have also lost their role as the protagonists.

The political agents are taking an opportunistic advantage of the visibility that crime has in the social discourse by impetuously incorporating into their agendas all types of rash criminal policy proposals. Criminal policy constitutes, even more than financial policy, the area in public policy in which ideological and programmatic differences between political parties have blurred the most. The decisions adopted are, to a great extent, based on extremely superficial analyses of the social reality they intend to affect and of the effects the policies will produce, actually being conditioned by the echo they might have on those who claim to represent public opinion. As a consequence, they possess an unequivocally populist nature, their objective being, implicit though predominant, to obtain immediate support for their political performance or to gain electoral benefits.

An example from the left-wing majority party, from which these attitudes are more surprising, is the campaign of the socialist opposition between 2001 and 2003 which was based on maintaining, quite unfoundedly but with a clear intention of undermining the credibility of the right-wing government, that crime in Spain was escalating ${ }^{14}$. The campaign, which had a strong initial impact on the media with a closer affinity to leftist political parties and then on the rest of the media, had a disastrous impact on the reforms of the criminal code that took place in 2003, supported by both majority parties.

Another good example can be seen through the deplorable struggle between the two majority parties, especially between 2008 and 2010, in which the rest of the political forces finally participated, to take advantage of the social indignation created by the so-called "Mari Luz case", which allowed the spokesperson of the victim's family to obtain repeated interviews and contacts at the highest political level, to push ad hoc parliamentary motions, and even to receive offers, some of which were accepted, of important positions in political parties.

However, it is interesting to note that social attitudes, empirically measured, are reluctant to make crime a priority on the social agenda.

\footnotetext{
${ }^{14}$ Actually, there was a slight increase in the levels of crime in 2001 and 2002 that stopped in 2003. García España Pérez Jiménez, Seguridad ciudadana y actividades policiales, Informe ODA 2005, IAIC-Fundación El Monte, 2005, p. 25. See an analysis of the campaign on the newspaper El País and its impact on the levels of fear of crime in Soto Navarro, La delincuencia en la agenda mediática, op. cit. pp. 84-122, 125-127. Similarly, Díez Ripollés, El aumento de la criminalidad y la izquierda, Newspaper El País, May 9 $9^{\text {th }}, 2002$.
} 
On the one hand, fear of crime among the population, measured through surveys carried out by the CIS, is not considered to be amongst the three most important personal problems, except during very short periods connected to specific political campaigns $^{15}$. Crime surveys also indicate that $66 \%$ of the citizens feel safe walking alone in their neighbourhood at night, with only $9 \%$ of people feeling afraid to go out or who go out feeling very unsafe; moreover, $89 \%$ of the citizens feel safe at home alone, whilst only $1.4 \%$ feel very unsafe ${ }^{16}$.

On the other hand, Spanish citizens show, in general, very moderate punitive attitudes. This is clearly reflected through research which draws the distinction between their perceptions on the levels of crime, undoubtedly influenced by discourse transmitted primarily through the mass media, and their opinions on how certain specific alleged crimes should be punished:

In this sense, $90 \%$ thinks, in contrast to actual reality, that crime has increased considerably or a fair amount in our country during recent years, and over $85 \%$ believes that criminal penalties in our country are lenient, very lenient or inappropriate.

Nonetheless, when faced with, for example, a specific burglary carried out by a recidivist offender and asked what punishment they would impose, citizens are noticeably less harsh than the criminal code dictates in Spain. Whilst according to case law this conduct would be punished with a prison sentence of approximately three years, only $21 \%$ of Spanish citizens think it is correct to impose a prison sentence for this behaviour, and $87 \%$ of those who believe so would impose a prison penalty of less than three years ${ }^{17}$.

Experts and agents of the criminal justice system, apart from suffering great social discredit ${ }^{18}$, or precisely because of this, have become irrelevant. In part, this has been the result of the exclusion and despise which they have been subjected to by political agents, mass media and non-expert pressure groups, in order to make sure that they would not hinder their interests or actions. There are, however, other motives: in particular, their incapacity to introduce their skill and expertise into the current conditions of public and political debate in a way that they can orientate their evolution towards reasonable objectives. As such, the absence of expert pressure groups with sufficient influence capacity stands out ${ }^{19}$. Neither is it possible

\footnotetext{
${ }^{15}$ See the opinion barometers of the CIS for the last years in http://www.cis.es. In 2003, after the aforementioned socialist campaign on the media, the level of fear of crime was raised, for a short period of time, to the third and even second places of the most important individual problems. See references in Díez Ripollés, El nuevo modelo penal..., op. cit. p. 8, footnote 10 .

${ }^{16}$ See Díez Ripollés/García España drs., Encuesta a víctimas en España, op. cit. pp. 46-50.

${ }^{17}$ See Díez Ripollés/García España drs., Encuesta a víctimas en España, op. cit. pp. 155-160. These results, which also appeared for other frequent types of crimes - see Varona Gómez, Ciudadanos y actitudes punitivas, Revista española de investigación criminológica (REIC), www.criminologia.net $\mathrm{n}^{\circ}$. 6. 2008, pp. 14-17, cannot prevent us from ignoring the increasing signs of the progressive intolerance towards physical violence that is being registered in our society, which generates more rigorous attitudes towards violent criminal behaviour.

${ }^{18}$ See above.

${ }^{19}$ The different judge and prosecutor associations, when not occupied with their corporative interests, tend to cancel each other out due to their respective, and in occasions strict, partisan relations. A transversal, academic and judicial group, the Grupo de estudios de Política criminal www.gepc.es, is far from having achieved its full potential.
} 
to leave aside how easily these experts and agents are influenced by those who hold political or media power to the extent that they are greatly phagocytised by them. At best, they adopt strongly sympathetic approaches that restrict their role to simply making palatable lines of argument and programmed activities previously established by these powers; in the worst cases, they end up as merely pompous figures that give a technical shine and apparent legitimacy to criminal policy decisions they do not share, but do not challenge either ${ }^{20}$.

\section{Inconsistencies of current criminal policy}

The conventionally established correlation between volume and intensity of the crime control system and the volume and severity of the criminality that is to be controlled does not correspond to the facts. Without denying that a greater presence of criminal behaviour would inevitably intensify the reaction of the public institutions in charge of pursuing them, what is true is that a criminal justice system is not fundamentally explained by the number and types of crime it must deal with. The configuration of crime control in a particular country is, to a great extent, the product of previous political decisions on how it is supposed to be implemented, and only later will this model be applied, albeit in a limited manner, to the real necessities of the fight against crime ${ }^{21}$.

This sequence, besides corresponding to reality, does not present legitimacy problems to institutional behaviour; reducing crime levels is simply another public policy that is conditioned not only by the reality it must face, but more significantly by the principles to be followed in any social intervention, together with the socially acceptable means to be adopted in the pursuit of public objectives, among other variables. What is not legitimate, however, is to pretend that certain practices or outcomes are the inevitable consequence of a reality that, nevertheless, allows other approaches.

A good example of this disconnection between criminal reality and the crime control system is the Spanish criminal policy situation: a low crime rate in comparison to the rest of the European countries over the last decades has led, in a very short time, to a rate of imprisonment that tops first place in Western Europe. It does not seem convincing to argue that the reason for this increase has been to anticipate an expected growth in crime rates. Everything indicates that this is the result of a political choice that has opted to hinge the criminal justice system on an excessive use of the prison penalty.

\footnotetext{
${ }^{20}$ An analysis of external experts, proceeding mainly from the academic field, who have participated in several recent criminal reforms, would probably give some illustrative examples.

21 This is a predominant opinion in current criminology. See Tonry, Thinking about Crime, Oxford University Press 2004, p. 14: Lappi-Seppäla, Trust, Welfare and Political Culture: Explaining Differences in National Penal Policies, in Tonry (ed.), Crime and Justice, Vol. 37, The University of Chicago 2008, pp. 332-342.
} 
It is not true that political agents are forced to implement a harsh criminal policy because popular demands and the media leave them no alternative. Contrarily, it is the political agents who really shape the criminal policy agenda.

Reliable studies have shown the dependence the media has on the information, or lack of information, provided by official sources, which constitutes the main part of the material with which they later elaborate their contents ${ }^{22}$. Directly related to criminal policy we have good examples in Spain in both senses: it has become common practice that the police or the public prosecutor's office, often instructed by the central bodies, call the media to account for those actions they are interested in publicising, even before the judges receive the police reports, complaints or other relevant documents. Conversely, the Ministry of Interior, which the Interior Department of Catalonian autonomous government later joined, has since 2007 implemented a policy of obscurantism, if not of interested incompetence, when putting together and publishing the police crime statistics data ${ }^{23}$. They thus make sure that no independent analyses can be carried out from the data they present with the format, limitations and biases, and at the time of the year, that they deem more convenient for their immediate political interests.

The partisan trivialisation of the public debate on crime and the reaction towards it promoted by political agents is a repeated practice; knowing the repercussions that most of these issues have on popular concerns, they frequently use them as a smokescreen that veils other, more compromising issues for their political performance. To this they add their adherence to lay approaches, which pretend to be seen as common sense, for dealing with crime, undermining more detailed analyses that would force them to carry out tasks that are more complex to implement. Thus, they build an agenda that is disproportionately focused on problems, real or apparent, on which they can easily rely on popular support, and for whose solution they can adopt measures that lack technical standards but bring significant electoral benefits.

The use of victim pressure groups as undercover agents of political groups contributes, without doubt, to the pursuit of this latter effect; these are used as collision forces that clear the path for the achievement of their electoral objectives. Knowing their appeal and their capacity of mobilising public sentiments, they uncritically assume many of their positions and legitimise a priori their proposals, thus making it practically difficult, or costly in terms of image, for other social agents to challenge their arguments and present other alternatives.

As protagonists in shaping the criminal policy agenda, the political actors must also exert strict control over the agents of the criminal justice system, since it is they who, due to their close contact to the criminal reality, may question these proposals arguing from their daily experiences. This need is one of the motives, among others, which has led political actors to devote their efforts to undermining the prestige of

\footnotetext{
22 Among the first authors who highlighted this reality, see Beckett, Making Crime Pay, Oxford University Press, 1997, pp. 62-78: Beckett/Sasson, The Politics of Injustice, Sage Publications 2000, pp. 73-79.

${ }^{23}$ See above reference 1.
} 
the justice administration. The continuous losses of autonomy of the judiciary is only a part of a movement of greater significance that intends to finish with the division of powers of the democratic state ${ }^{24}$; the so-called politicisation of the directive organs of the judiciary and, as a consequence, of numerous important appointments in jurisdictional positions, is increasingly depriving many judicial decisions of their credibility. Furthermore, the incapacity of political parties to isolate the justice administration from partisan struggles adds to this situation, thus producing judicial expertise that is persistently discredited in such a way that judicial decisions are compared to decisions of a political nature. It is thus not surprising that one of the common trends of all criminal law legal reforms in recent years is the progressive suppression of judicial discretion ${ }^{25}$.

The criminalisation of public policies, that is, the idea that the solution to any social problem or conflict must lead, sooner or later, to punishing, or strengthening punishment of, the behaviour that generates it, constitutes another of the inconsistencies of our current criminal policy. Such beliefs ignore the vast number of mechanisms of social intervention and assistance that tend to be available in developed societies, and end up reducing all public policy to a policy of law and order ${ }^{26}$. Numerous decisions of criminal policy during the last few years show clear signs of this approach, such as the punishment for the non-payment of alimonies, the conversion of non-serious domestic and partner violence into a crime, the harshening of the juvenile criminal justice system, or the expansion of crimes against road traffic, among others.

Actually, this simplification of policies, that some author has named "governing through crime" 27 , is nothing other but the complete resignation to the development of the welfare state, and thus produces a set of negative effects among which the following are of interest for the purposes of this article:

The intention of solving a good deal of social problems by means of the frequent and intensive use of the harshest means of state coercion triggers or widens social exclusion phenomena for an increasing number of people and communities; this will necessarily hinder the efforts to guarantee social stability and integration, by creating new and more serious problems, if not also worsening those that lie at the origin of this policy.

At the same time, the overload of the penal system to which this political strategy leads to, ends in de-naturalising the system itself, which must thus resign from pursuing its own objectives, and substitute them for other not so well-founded

\footnotetext{
${ }^{24}$ This has already practically been achieved with regard to a legislative power which is strictly controlled by the executive power or by the executive boards of the political parties.

${ }^{25}$ Regarding the reforms of 2003, see Díez Ripollés, El nuevo modelo penal de la seguridad ciudadana, op. cit. p. 12; regarding the reform of 2010 originated in the 2009 project, Díez Ripollés, Una reforma penal para abandonar, Boletín Jueces para la democracia, n 51 , July 2009, p. 4.

${ }^{26}$ See Díez Ripollés, La criminalización de las políticas públicas, Newspaper El País, July $3^{\text {rd }}, 2008$.

27 The expression "governing through crime" has been made popular by Simon in his work "Governing through Crime. How the War on Crime Transformed American Democracy and Created a Culture of Fear, Oxford University Press 2007.
} 
objectives. Finally, the neutralisation of the penal system, despite its transformation, poses a threat which is just around the corner.

\section{Recovering a well-founded policy}

Redirecting criminal policy towards a better-founded path requires the recovery of the ideological coherence of the social agents that determine its configuration. This implies taking a stance on a number of previous issues, of which two of the most important shall be mentioned.

Criminal policy is just one policy more among the whole set of public policies and must, hence, correspond to the general objectives pursued by the respective political programmes. In other words, it cannot function as an instrument of social and political agitation, with the primary mission of wearing down the adversary or of producing a massive movement of votes, in such a way that its content remains at the mercy of immediate electoral interests.

Its insertion in consistent political programmes implies that the objectives and the means to be employed for their achievement are clearly set. We need to know, in the first place, whether the eradication of certain types of criminal behaviour or even of crime in general is a feasible objective, or if we must settle with reducing the frequency and/or severity of certain criminal conducts or of crime in general, and to what extent.

On the other hand, having assumed one or another of these objectives, a question emerges that will inevitably define the modes of intervention to be employed and the consequences they might have on the social structure: whether the social interventions of criminal policy are seen as a vector for social transformation or simply as an instrument for the maintenance of the status quo.

Knowing the importance given to the achievement of the chosen objective is also decisive: if it is a priority to be obtained at almost any price, we must be informed, for example, to what extent is its pursuit perceived to be compatible with a strict respect of the current principles of rule of law or whether these must be reformulated to a certain level, as well as the economic resources that will be allocated. On the contrary, if this objective is just one among others, we must have sufficient information on how seriously this commitment has been assumed.

The answer to all these questions must not be rhetorical. The choice over one or another of the depicted alternatives has an important impact on the whole set of public policies, which will be affected in different forms.

Turning now to the second of the issues we mentioned, the opposition between criminal policy seen as an agent of social transformation or as a mechanism of stabilisation of the current social structure forms part of a social debate of greater scope: the extent to which the social inclusion / social exclusion dimension of the members of society plays a protagonistic role in the configuration of any public policy. 
Applied to the field of criminal policy, this dichotomy entails substantially different ways of proceeding. If, to say it bluntly, we focus on those who already carry a sentence on their shoulders, an inclusive criminal policy would intend to improve or, at least, not worsen the individual and social conditions for whoever has already been subjected to criminal law to live according to the law; this requires fostering integrative measures of social intervention as well as re-integrative measures of individual intervention. If, conversely, we adopt an approach that excludes or, more frequently, one that does not take interest in the needs of social inclusion, , this will result in measures which only ensure that after the sentence has been served, the ex-felon will find individual and social conditions for committing further crimes, and not to be discovered, more difficult; this calls for measures of social intervention that segregate certain collectives, together with measures of individual incapacitation.

In the author's opinion, the inclusive approach guarantees a decrease in the levels of crime in the medium and long-term, whereas the second approach fosters its increase in the same period. Moreover, the social inclusion alternative is related to social welfare, and thus forms part of the political project of building a welfare state and society.

Either which way, our political leaders owe us an explanation. We have a right to know whether criminal policy is still a sector of public policy, to be formulated in coherence with the ideology which inspires the approach to social problems by the different political forces, or whether it has been incorporated to the collection of malleable strategies to be used, according to the circumstances, in the political struggle.

Even if the answer is the first alternative, many of us need to know whether the left-wing political forces have reached the conclusion that there is no alternative in criminal policy and no other option but a populist and socially excluding criminal policy, as they seem to believe with other public policies.

\section{Urgent tasks}

One of the most urgent tasks to be pursued by a criminal policy programme which corresponds to the current social principles and needs is a reform of our sanctions system, in its substantive as well as in its enforcing level. I don't believe it is exaggerated to assert that the configuration and practice of our current sanctions system suffers from three basic flaws, making it obsolete, unjust and inefficient ${ }^{28}$.

Our sanctions system is obsolete because it is disproportionally based on custodial sentences and because up until now it has been unable to develop, as opposed to the majority of the countries in our region, a set of sanctions other than prison with an effective and convincing enforcement capacity. We have probably reached this

\footnotetext{
${ }^{28}$ See Díez Ripollés, La evolución del sistema de penas en España: 1975-2003, Revista electrónica de ciencia penal y criminología (RECPC), http://criminet.ugr.es/recpc 08-07., 2006, pp. 23-25; same author: La reforma del sistema de penas, Newspaper El País, November $26^{\text {th }}, 2005$.
} 
anomalous situation because the demands of renovation of our sanctions system, sometimes formally transformed into law, have always come from expert sectors, whilst other social and political actors, dazzled by the powerful penitentiary image, have never assumed or legitimised them.

Fine penalties, despite being correctly regulated in general terms, are imposed and applied in an extremely defective manner and constitute, dare it be said, the great flaw of our penal system. The monetary amounts imposed are usually indiscriminately low; in any case, they hardly correspond to a prior analysis, as required by law, of the income of the offender, and its effective enforcement is far from good. If we ask ourselves as to the causes of this situation, we discover a combination of judicial routines in which dedicating a significant period of time to the precise determination of the amount of the pecuniary penalty does not constitute a judicial task and, to a lesser extent, the evident lack of human and material resources for making and implementing such a judicial decision. As long as fines are not practically credited as a serious and useful penal reaction, it is futile to dedicate our efforts to an indispensable legal reform, in which fines should become the only foreseen penalty for a large number of crimes, as opposed to current regulation in which it is frequent that it complements other punishments, in particular -and incongruentlyprison sentences.

We could also add some important reflections on the community service penalty, which, despite its almost marginal incorporation to the criminal code in 1995, due to its limited field of application, has been increasing its scope through different subsequent legal reforms. However, its implementation has clashed with the painful reality of our extra-penitentiary sanctions enforcement system. It is hard to accept that, apparently, what currently best characterises this penalty is its proclivity not to be applied due to its statute of limitation; the increase in the number of cases in which the penalty is imposed after the recent reforms, the lack of human and material resources of the corrections administration ${ }^{29}$, and the reluctance of very different institutions to provide workplaces or activities where this penalty can be served, have led to this unsatisfactory situation.

On the other hand, the development that new sanctions or reconfigured traditional penalties are acquiring thanks to certain technological advances, and whose benefits are being closely examined in other legal systems, is overshadowed in Spain by the leading role of the prison penalty. This is the case, in the first place, of electronic monitoring; originally conceived as an instrument to improve the control of personal precautionary measures, probation, open prison regime and conditional release, it is now increasingly becoming an autonomous penalty that occupies a privileged place before prison penalty in sentences of moderate severity. Nothing of this occurs in our country, where only custody seems to meet the necessary afflictive contents these moderate offences deserve ${ }^{30}$.

\footnotetext{
${ }^{29}$ Despite the significant progress achieved in the expansion and modernisation of the open prison regime centres - CIS (its acronym in Spanish).
} 
What has occurred with the preventive measure of controlled release is even more symptomatic. Instead of being structured as a penalty that could replace prison for minor offences ${ }^{31}$, a possibility which is in force in other legal systems, it has been used for the reintroduction of the idea of criminal dangerousness in Spanish criminal law. The 2010 criminal code reform has actually transformed it into an additional penalty in real terms, to be served once the convicted person has served the prison sentence, during a period of up to 10 years. Its justification, to be judged by the content assigned to the measure, essentially revolves around the persistent dangerousness attributed in general to individuals who commit certain crimes, in particular of sexual and terrorist nature, and the need to ensure their incapacitation once they are set free. We find ourselves before a manifest sign of an ideology of social exclusion in the approach to crime which, besides responding to scarcely founded archetypes and generalisations on the future behaviour of certain offenders ${ }^{32}$, it supposes the clear recognition that the penitentiary system is not in conditions to achieve what is one of its main constitutional objectives, the re-education and reintegration of offenders. The risk a punishment like this has of net widening has not, on the other hand, been considered.

However, whilst we drag our feet when we try to innovate towards sanctions that reduce the importance of prisons in our criminal system, new versions of custody have easy access to our catalogue of sanctions, such as the recently extended permanent location, transformed without concealments, given its extension and possible place of enforcement, in a re-establishment of the old prison arrest ${ }^{33}$.

Our sanctions system is moreover unjust, since the omnipresent prison penalty is used in an unnecessarily rigorous way. As opposed to what is usually believed, we do not have high incarceration rates because we send many citizens to prison; the volume of sentences generated by our criminal system is moderate compared to other countries $^{34}$. What we do instead is to keep those convicted in prison for a long period of time.

This is due, on the one hand, to the continuous increase of the duration of prison penalties envisaged for different criminal offences and, on the other hand, to the

\footnotetext{
${ }^{30}$ One of the most determined countries in the use of electronic monitoring as an alternative to short prison sentences has been Sweden. See references, for example, in Cavadino/Dignan, Penal Systems. A Comparative Approach, Sage Publications 2006, pp. 158-159. The Grupo de estudios de Política Criminal, in its volume "Alternativas al sistema de sanciones penales: Nuevas penas y medidas restrictivas de derechos", 2011, forthcoming, proposes a wider use of electronic monitoring within the recommended penalty, as an alternative to prison, of controlled release.

${ }^{31}$ See the aforementioned proposal.

${ }^{32}$ To counteract erroneous assumptions on recidivism of sexual offenders, see Soler Iglesias/García Díez, Delincuencia sexual y reincidencia. Un estudio en las prisiones de Cataluña, in: Centro de estudios jurídicos y formación especializada, Delitos sexuales y reincidencia, 2009, pp. 120-121; Redondo/Navarro/Martínez/Luque/Andrés, Evaluación del tratamiento psicológico de los agresores sexuales en la prisión de Can Brians, Boletín criminológico, $n^{\circ} 79$. 2005, passim. Some general reflections from these and other data, in Díez Ripollés, Una reforma penal a abandonar", op. cit. p. 4.; Cid/Tébar, Libertad condicional y delincuentes de alto riesgo, Revista española de investigación criminológica (REIC), www.criminologia.net no 8, 2010. p. 18.

${ }^{33}$ See articles 33.3.1 and 37 of the criminal code after its reform by LO. 5/2010.

${ }^{34}$ See statistical references in Tamarit Sumalla, Sistema de sanciones y política criminal. Un estudio de derecho comparado europeo, Revista electrónica de ciencia penal y criminología (RECPC), http://criminet.ugr.es/recpc 0906. 2007.p. 17; Cid Moliné, El incremento de la población reclusa, op. cit. pp. 4-5, 9.
} 
incessant harshening of the penitentiary regime. The criminal code of 1995 represented a significant inflection in this sense, not only for the suppression of practically all automatic prison benefits, such as the shortening of penalties due to good time credits, but also for the verifiable increase of prison penalties for frequent crimes of medium to low severity. The path initiated by the new criminal code has been confirmed over and over again by successive reforms that have taken place ever since then. Those that took place in 2003 were especially important due to the general harshening of the penitentiary regime that brought about greater difficulties or delays to obtain the open prison regime or conditional release, as well as other prison benefits ${ }^{35}$, and because they extended the situations in which pre-trial detention $^{36}$ can be ordered, among other rigorous decisions. What's more, a fainthearted Supreme Court, unable to resist political and media pressures, introduced new counting criteria for the accumulation of penalties in 2006 which, apart from being constitutionally arguable, have had noticeable effects on the prolongation of the sentences on crimes judged under the previous criminal code ${ }^{37}$.

The 2010 reform contains provisions that may have a clear incidence in shortening prison stays, such as a reduction of the situations in which open prison regime cannot be applied until half the sentence has been served, or the possibility of lowering the duration of prison penalties in the less serious drug-related crimes. It is, nevertheless, another example of the compulsive tendency to increase the length of prison penalties for traditional crime, in this case particularly through the increase of the minimum penalty for sexual offences, among others, and through the establishment of generalised aggravations for situations of criminal cooperation ${ }^{38}$.

The fact is, for these and other, similar reasons, the average stay in Spanish prisons doubles or triples the average European figures, parole is enforced in extremely low percentages as the last phase of serving a prison sentence ${ }^{39}$, the level of overcrowding in most of our prisons cannot be compensated by the frenetic construction of new correctional facilities, unique in Europe ${ }^{40}$, and the renewed efforts of the

${ }^{35}$ See Díez Ripollés, La evolución del sistema de penas..., op. cit. pp. 20-21; Cid Moliné, El incremento...”, op. cit. pp. 17-22; Cid/Larrauri, Bericht Spanien, op. cit. pp. 791-794. Nevertheless, it must be pointed out that as of 2004, coinciding with the change of government from the Partido Popular to the Partido socialista obrero español, there is a change in tendency by virtue of which the percentages of inmates (especially in the open prison regime, and to a lesser extent on parole) increase once again. This is product of a different penitentiary enforcement policy, not of a new criminal legislation policy. See Gallego/Cabrera/Ríos/Segovia, Andar $1 \mathrm{~km}$ en línea recta. La cárcel del siglo XXI que vive el preso, Publicaciones de la Universidad Pontificia de Comillas 2010, pp. 27-29, 45-46; Cid/Tebar, Spain, in: Padfield/van Zyl Smit/Dünkel, Release from Prison. European Policy and Practice, Willan Publishing 2010. pp. 380-383.

${ }^{36}$ See the reform of the pre-trial detention regulation that took place with LO $13 / 2003$ of October $24^{\text {th }}$. Data on the continuous increase in both absolute and relative terms of the use of pre-trial detention, starting in 2001 but accelerating in relative terms as of 2004, can be found in Díez Ripollés/Guerra Pérez, Pre-trial Detention in Spain, European Journal of Crime, Criminal Law and Criminal Justice, vol. 18, issue 4, 2010, pp. 388-390; Gallego/Cabrera/ Ríos/Segovia, op. cit. pp. 33-34.

${ }^{37}$ See STS. 28-2-2006 that formulates the Parot doctrine.

38 The latter through the expanded notion of "organised group".

${ }^{39}$ See the mentioned data above.

${ }^{40}$ In clear contrast, for quite a long period of time in some Northern countries there has been a policy of not building more correctional facilities in order to foster the alternatives to prison. See, among others, Pratt, Scandinavian Exceptionalism in an Era of Penal Excess, Part. I, British Journal of Criminology 48, 2008, p. 135. 
penitentiary administration to expand the offers of treatment and re-socialisation stumble down time and again with the stubborn reality of a country that seems to be determined to keep a significant sector of its population, almost two in every one thousand people, behind bars.

Spain's sanctions system is, in short, inefficient. It is the result of an obsolete analysis on the nature of the personal interests liable of deprivation or restriction by the sentence in order to achieve the objectives intended by the punishment.

Let us leave out the reintegration aims, of which it is not necessary to argue that the expansive use of the prison has had counterproductive effects. Let us also discard the goal of incapacitating or neutralising the offenders by the simple provision of locking them in prison as long as possible: we cannot, either ethically or economically, keep in confinement for a long or practically indefinite period of time an increasing number of our citizens for the mere fact that, having committed a crime, we fear they will commit another.

If we focus our attention on the intention of deterring either the offender, potential offenders or members of society in general from committing crimes, the threat of imprisonment to whoever commits a crime is not the best option. The social and welfare state which, with all its imperfections and incidental regressions, has been consolidating in Spain over the past few decades, has generated a consumer society in which the catalogue of personal interests that may be legitimately intervened upon, by way of crime deterrence, is far from being limited to the freedom of movement.

With Spanish society being placed among the top group of the most developed and rich societies of the planet, albeit with all the inequalities that no doubt exist, it ensues that a great number of our citizens have access to economic goods of a certain importance or, in other words, have something to lose if the State has an impact on their personal assets in some way ${ }^{41}$. All the same, we continue to waste the effectiveness of a serious implementation of pecuniary penalties, with the ability to negatively influence the level of income and, if required, the lifestyles of those convicted. Other important European countries have managed to shift the emphasis of their sanction system from imprisonment to fines, making their crime control system more efficient without losing an inch of deterrent force ${ }^{42}$.

Similarly, it is difficult to understand how a society like the Spanish, with a strong and proactive public administration in fostering social and economic activities for

\footnotetext{
${ }^{41}$ One could reply that most offenders do not possess any property. This, however, implies two assumptions that immediately bring up, at least, two other issues that must be answered before we continue with this line of argument. The first supposes that crimes are committed in particular by the economically underprivileged sectors of society, and the question that emerges is whether, this being true, it is ethically and politically correct to react against the criminality of this sector giving priority to prison sanctions. The second supposes that especially harmful social behaviours, which are the target of criminal law, are mainly identified with those carried out by individuals without economic resources or with, to put it one way, unstable resources. The question that should therefore be answered is whether it is realistic in a developed society like Spain to consider that the potentially most harmful behaviours for social coexistence and on which the punitive reaction must focus are those of traditional, street, or outliers criminality, or whatever we prefer to call it.

${ }^{42}$ See the references to Germany, among other countries, in Tamarit Sumalla, op. cit. pp. 31-38.
} 
ensuring the personal progress of its citizens, does not use its capacity to transform the sanctions system in such a way so that it restricts certain social services and benefits that all citizens are, in principle, entitled to. It is not simply a reformulation and reconfiguration of some punishments so that they act as actual deterrents, such as professional incapacitation.. We must also continue or effectively implement new penalties that hinge upon the deprivation or restriction of a wide range of economic and social benefits, and whose absence does not hinder but does make more difficult the development of the personal life plans of citizens. Leaving aside those provisions directed towards social assistance and securing basic rights, and putting special zeal into counteracting the possible de-socialising effects ${ }^{43}$, there is still a long way to go in the field of direct and indirect economic aids, subsidies, tax exemptions, access to public contracts or to publicly funded economic or social activities, etc.

None of these alternatives to our sanctions system seem to be in the minds of our policy makers. It is no longer that we lack long-term proposals to restructure our inefficient punitive catalogue. Moreover, in recent legal reforms where a significant part of the new forms of criminal behaviour to be punished or punished more severely are moderate crimes, prison, once again, is the penalty par excellence. This is the case of the so-called law against gender violence of 2004 or road traffic crimes.

The second urgent task to be pursued by any Spanish criminal policy programme is the unavoidable modernisation of our justice administration, in general, and of our criminal justice administration, in particular. With no doubt, this modernisation must ensure, as its primary objective, that social conflicts that must be treated in legal terms and, in this context, the exercise of crime control, are resolved in a fair and effective manner.

It is of interest to simply highlight here that only a justice administration that shows capacity to tackle the tasks they are entrusted with may recover its prestige. Furthermore, only after obtaining such social credibility and trust, today notably disrupted, may its expertise acquire the status it deserves in principle, and thus be in conditions to resist the attempts of manipulation by political, social and media actors. Without becoming too naïve to believe in or too inconsistent to wish for a justice administration isolated from social vicissitudes, criminal policy would gain a lot in rationality if society bore out that many social conflicts may be left to the judicial discretion and judgement.

In the author's opinion, the modernisation of the criminal justice administration is not so much a problem of lack of human or material resources, as a problem of management of these resources. The judicial staff does not show the dramatic deficiencies it showed not many years ago and, in any event, solutions can no longer stem from a continuous expansion of human resources. Economic resources will never be sufficient but, after significant budgetary increases, the focus should be

\footnotetext{
43 On the enormous socially disintegrating potential of the deprivation of rights related to serving a sentence, see examples of United States in Uggen/Manza/Thompson, Citizenship, Democracy and the Civic Reintegration of Criminal Offenders, Annals of the American Academy of Political and Social Science. 650, May, 2006, passim; Harris/Beckett/Evans, Drawing Blood from Stones: Legal Debt and Social Inequality in the Contemporary United States, American Journal of Sociology, Vol. 115, nº6, 2010, pp. 1753 et seq.
} 
changed towards the correct allocation of these. Not even the well-known rhetorical cliché that criminal justice is slow corresponds to reality ${ }^{44}$; without ignoring that there is room for improvement, the focus must be moved to other jurisdictions. In sum, what we need is to introduce into the aforementioned institution a set of good practices and managerial techniques ${ }^{45}$. What follows are some ideas on this matter.

This implies, in the first place, reforming the procedure of public entrance into judiciary and public prosecution careers. What must be achieved, first and foremost, is that the acquisition of the abilities for the entrance qualification does not place demands on the applicant's social and economic resources that cannot be met by significant social sectors. Hence, the necessity to provide the corresponding educational framework and public aids. The primary objective must be to guarantee that candidates show themselves to be skilled in a set of capacities and competences that adjust to the real necessities of the functioning of the judiciary, something that does not occur nowadays; it would be wrong to reject theoretical or practical examinations that directly prove the level of legal knowledge acquired by the applicant, although they should be preceded by character tests, capable of preventing from further progress in terms of the entrance procedure those who do not show, among other characteristics, analytical consistency, emotional stability, empathy, and resistance to pressure that daily experience reveals as qualities of a good judge or public prosecutor. In addition to these, a good level of legal knowledge among other competences are also necessary, such as a good discursive and argumentative capacity with regards to specific cases, and knowledge and interests that go beyond the legal field, in order to adequately contextualise any legal decision. Perhaps these new demands may lead to delaying the age at which someone is eligible to take part in public entrance examinations, so that candidates have had the opportunity to acquire other juridical and life experiences after finishing their studies in law. In any case, the configuration of this procedure as objective and impartial is an asset that must not be placed at risk by the unavoidable aforementioned modifications ${ }^{46}$.

Just as necessary as that which was just mentioned is the transformation of the promotion system of magistrates and judges to middle and high levels of jurisdiction according to objective criteria of merit and capacity. It is well known that the situation has reached levels of untenable associative and political patronage ${ }^{47}$, complemented by a generalised ostracism of half of the judges, as long as they are not associated. As long as we are incapable of embedding this culture of merit in the corporatist decision-making organs, it is preferable to adopt less nuanced but more

\footnotetext{
${ }^{44}$ See data on the average estimated duration of procedures of the different jurisdictions in Consejo general del Poder judicial, La justicia dato a dato. Año 2009, pp. 81et seq.; likewise, the data obtained in an empirical study financed by the Consejo general del Poder judicial, on the duration of drug-related procedures until a final decision is taken in Muñoz Sánchez/Díez Ripollés drs, Las drogas en la delincuencia, 2004 Tirant, pp. 150, 224-225.

45 Among the reflections formulated by those who suffer the problem from the inside, we must highlight those by Carmena Castrillo, Crónica de un desorden. Notas para reinventar la justicia, Alianza editorial 1997, passim.

${ }^{46}$ See a recent collection of different national systems of access to the judiciary career in Rodriguez Ruiz, Los sistemas de selección de jueces en Europa: un estudio comparado, Jueces para la democracia, $\mathrm{n}^{\circ}$ 69, 2010, passim.

${ }^{47}$ See above.
} 
objective criteria, such as seniority or credited productivity ${ }^{48}$. It is a last resort to come out of a perverse dynamic that is rapidly and justifiably undermining the credibility of the judiciary. The comprehensible preoccupation that these criteria will promote a majority conservative ideological bias in the judiciary, given the predominant social background of the judges, must be taken into account beforehand; as we have pointed out, it is imperative that judiciary and public prosecution careers become attractive to candidates from any social extraction, with which it should ensue that preparation for the entrance exam really is a possibility open to everyone.

On the other hand, an especially heartbreaking feature of the justice administration is the poor autonomy of the highest ranks of public prosecutors with regards to the executive power, something which, to a greater or lesser extent, is passed down the ranks throughout its hierarchical structure. As long as the public prosecutor does not enjoy a fully autonomous status, proposals that are intended to make public prosecutors competent to carry out preliminary proceedings or to reduce the use of popular action, have to be reluctantly considered. In a time when criminal law is struggling to stop being the law that applies exclusively to the underprivileged sectors of society, and intends to be enforced in relation to socially harmful behaviours in the economic, administrative and political fields, reforms like those announced could become a guarantee of impunity for the powerful sectors ${ }^{49}$.

Likewise, the unavoidable improvement in a better use of human and material resources demands that the judicial governmental organisms undergo a significant revocation of its administrative, inspective and disciplinary functions. What has just been asserted may seem surprising, but if we want the justice administration to take fair and effective decisions in a context of efficiency, it is necessary to introduce important reforms in the judges' self-government.

The current establishment of a common and centralised judicial administration unit is supposed to imply notable progress in the rationalisation of the justice administration operations ${ }^{50}$; in the first place, this dynamic has created the fortunate decision of significantly increasing the power of clerks, as well as introducing other improvements in the regulation of the different jurisdictional procedures ${ }^{51}$. Secondly, the creation within the framework of the judicial administration unit of

\footnotetext{
48 That is, confronted with its conformity to decisions adopted by the appeal bodies.

${ }^{49}$ See a detailed line of argument against ascribing investigations to the public prosecutor, in its current functioning conditions, in Gómez Colomer, El sistema de enjuciamiento criminal propio de un estado de derecho, Universitat Jaume I/Instituto nacional de ciencias penales, 2008, pp. 116-133, 224-225, 230; same author, La instrucción del proceso penal por el ministerio fiscal: aspectos estructurales a la luz del derecho comparado, in: Gómez Colomer/ Gonzalez Cussac coords, La reforma de la justicia penal. Estudios en homenaje al Prof. Klaus Tiedemann, Ed. Universitat Jaume I. 1997, pp. 459 et seq.

${ }^{50}$ It is also to be expected to find an important improvement in management with the generalisation of the digital files, which will probably eliminate to a great extent the use of paper in these procedures. At the beginning of 2011, the works of digitalisation of the National audience were being finished, the first jurisdictional organ in which it is has been implemented. See newspaper El País, January $8^{\text {th }}, 2011$.

${ }^{51}$ Despite the fact that the obsolescence, as even the legislator recognises, of the current Law of Criminal Procedure has limited this rationalisation in the criminal jurisdiction. See Preámbulo. IV in fine of Law 13/2009, November $3^{\text {rd }}$, for the Reform of the procedural law for the establishment of the new judicial administrative unit.
} 
common procedural services offers the justice administration, as long as it is effectively implemented, a magnificent opportunity to overcome the ineffective and uncoordinated functioning of numerous judicial organs.

Nevertheless, the configuration of the new judicial administrative office has not entailed the managerial or organisational reform that is required for an efficient public service of justice. It does not seem reasonable to demand that clerks assume basically managerial functions of the justice administration, especially within the limited sphere of the judicial administrative office. Everything indicates that, within the complex distribution of competences between the judiciary on the one hand, and the ministry of justice or the corresponding organs of the autonomous communities on the other hand, the managerial tasks, which lie beyond jurisdictional and procedural spheres, should be assumed by the latter. Proof of this are the administrative units established at the LOPJ (Organic Law of the judiciary) ${ }^{52}$, in charge of the direction, organisation and management of most of the human resources, as well as the set of material resources of the judicial administrative offices; they are ascribed to the ministry of justice or organisms of the autonomous communities with transferred judiciary competences. The assumption of these managerial competences is, however, weighed down by the impossibility to adopt governmental decisions, to exert inspection over the judiciary or to participate in disciplinary control.

In the author's opinion, it would be extremely convenient to create a non judicial managerial body that would assume not only the administrative functions currently assigned to the ministry of justice or to the corresponding organisms in the autonomous communities, but also a good part of the managerial competences of the different magistrates and judges self-governed administrative organs. Such a body, whose parent body could be open to debate, would have a combined functional dependency, either of the general council of the judiciary, the ministry of justice or the autonomous communities, according to the functional competences carried out; it would moreover be constituted of civil servants with credited knowledge on organisational skills. Apart from assuming the aforementioned functions, it would be in charge of inspection duties, together with the investigation and decision proposal of disciplinary proceedings. From the author's point of view, a managerial organ, such as the one proposed, would be in condition to introduce the indispensable good practices in management, so necessary for such a complex public service as the justice administration, and which today are difficult to implement, due to the dispersion of competences among different administrations, in many cases without the proven capabilities of the staff for the tasks entrusted to them. Naturally, a proposal like the one depicted here requires, among many other things, a previous identification of the governmental tasks with direct jurisdictional implication, which would remain outside the activities of this managerial body, and a certain accommodation of its organisational structure to that of the jurisdictional organs it has to manage whilst guaranteeing, at the same time, their autonomy.

${ }^{52}$ See article 439 of the LOPJ, which foresees common support offices for several judicial administrative offices. 